Nadwa | Jurnal Pendidikan Islam

Vol. 11, Nomor 2 Tahun 2017

\title{
Budaya Sekolah Islami (Busi) : Studi Kasus di SMA Islam Sultan Agung 1 Semarang
}

\author{
Mustopa \\ UIN Walisongo Semarang \\ mustopa@walisongo.ac.id
}

\begin{abstract}
The value crisis has affected the Indonesian people in all areas of life including education. These conditions lead to the importance of intensive value education in schools. This paper aims to find out the concept of Islamic School Culture (Busi) and its implementation pattern in SMA Islam Sultan Agung 1 Semarang. The type of this research is descriptive qualitative. The result of the research shows that Busi in Sultan Agung 1 Semarang Islamic High School includes iqra 'culture, congregational prayer culture, thaharah culture, social interaction culture, and exemplary culture. The implementation pattern has been using top down with three step: socialization, habituation and monitoring. This pattern has succeeded in applying these Islamic values to unite in other school cultural activities in accordance with the vision, mission and objectives of the institution
\end{abstract}

Key word:Culture, Islamic value, school, pattern

\begin{abstract}
Abstrak
Krisis nilai telah menimpa bangsa Indonesia pada semua bidang kehidupan termasuk dunia pendidikan. Kondisi seperti ini menyebabkan pentingnya pendidikan nilai secara intensif di sekolah-sekolah. Tulisan ini bertujuan untuk mengetahui konsep Budaya Sekolah Islami (Busi) dan pola pelaksanaannya di SMA Islam Sultan Agung 1 Semarang. Jenis penelitian ini adalah deskriptif kualitatif. Hasil penelitian menunjukkan bahwa Busi di SMA Islam Sultan Agung 1 Semarang meliputi budaya iqra', budaya shalat berjamaah, budaya thaharah, budaya pergaulan islami, dan budaya keteladanan. Pola Pelaksanaan Busi dilaksanakan secara top down dengan tahapan sosialisasi, pembiasaan dan monitoring. Pola ini telah berhasil menerapkan nilai-nilai Islam tersebut menyatu dalam aktifitas budaya sekolah yang lain sesuai dengan visi, misi dan tujuan lembaga
\end{abstract}

Kata kunci: Budaya, nilai-nilai sekolah islami. pola

ISSN 1979-1739 (P) ; ISSN 2502-8057 (E).

(C) 2017 Nadwa | UIN Walisongo

http://journal.walisongo.ac.id/index.php/nadwa 


\section{Latar Belakang}

Indonesia saat ini sedang menderita krisis nilai dalam kehidupan berbangsa dan bernegara. Akibatnya berbagai penyimpangan, pelanggaran, dan dekadensi moral muncul diberbagai sektor kehidupan, baik pelanggaran hukum, pelanggaran norma-norma agama, dan berbagai penyimpangan nilai-nilai moralitas lainnya. Dan ironisnya, pelaku penyimpangan dan pelanggaran tersebut tidak hanya dilakukan oleh masyarakat awam dan tidak terpelajar, tetapi banyak dilakukan oleh masyarakat tingkat atas dan terpelajar. Apalagi ditambah dengan masuknya budaya asing, yang tentunya semakin menambah banyaknya persoalan nilai yang dihadapi oleh bangsa kita.

Masuknya budaya asing yang tidak sesuai dengan normanorma masyarakat Indonesia juga merupakan ancaman bagi nilai-nilai luhur yang dimiliki bangsa Indonesia yang akan menyeret generasi muda ke dalam perilaku destruktif atau menyimpang. Misalnya tentang kampanye para penyuka sesama jenis, yang dikenal dengan LGBT (lesbian, gay, biseksual, dan transgender) kepada anak-anak yang kini marak. Hal ini hendaknya menjadi perhatian yang besar dari berbagai pihak terutama pemerintah. Karena kalau kampanye tentang LGBT ini berhasil berarti kerugian besar bagi bangsa Indonesia yang ingin membangun peradaban mulia.

Krisis nilai tersebut menimpa pada semua bidang kehidupan termasuk dunia pendidikan. Kondisi seperti ini menyebabkan banyak pihak yang menyimpulkan tentang perlunya pendidikan nilai secara intensif di sekolah-sekolah kita. Pendidikan nilai yang diharapkan adalah bertujuan untuk mengurangi perilakuperilaku destruktif pada anak, remaja, dan orang dewasa. ${ }^{1}$

${ }^{1}$ Sofa Muthohar, "Antisipasi Degradasi Moral di Era Global," Nadwa 7, no. 2 (2016): 321-334. 
Mengingat semakin meningkatnya berbagai perilaku destruktif berkaitan kurangnya keteladanan bagi anak dan remaja. Oleh karena itu pendidikan nilai hendaknya dilaksanakan secara terarah, berkesinambungan, dan terintegrasi dengan penciptaan situasi yang kondusif. Pendidikan nilai hendaknya ditanamkan sejak dini melalui penerapan nilai-nilai keteladan tentang nilainilai kebaikan yang berakar dari agama, budaya, kewarganegaraan, dan kesepakatan-kesepakatan tentang nilai kebaikan.

Suyanto, selaku Dirjen Manajemen Pendidikan Dasar dan Menengah mengatakan bahwa mengajarkan nilai-nilai di sekolah tidaklah mudah. Banyak guru yang mengeluh karena sulit mencari bahan, tidak menguasai pendekatannya, bahkan mereka juga mempersoalkan bagaimana sulitnya mengevaluasi hasil belajar para siswa. ${ }^{2}$

SMA Islam Sultan Agung 1 Semarang yang memiliki visi dan misi untuk mempersiapkan generasi khaira ummah (generasi yang terbaik) terpanggil untuk mempersiapkan para siswanya menjadi siswa-siswa yang memiliki akhlak yang mulia, di samping memiliki pengetahuan dan keterampilan tentang ilmu yang dipelajari di sekolah, perlu menerapkan pendidikan yang menekankan pada penerapan pendidikan akhlak atau pendidikan nilai, yang kemudian dikemas dalam gerakan Budaya Sekolah Islami yang disingkat Busi. Jadi, Busi merupakan strategi yang diterapkan sekolah untuk pencapaian visi, misi, dan tujuan sekolah.

Bahasan dalam tulisan ini, penulis akan mengungkap secara berurutan konsep Busi dan penerapan Busi di SMA Islam Sultan Agung 1 Semarang. Metode pengumpulan datanya menggunakan observasi, wawancara, dan dokumen. Adapun

${ }^{2}$ Darmiyati Zuchdi, 2011, Humanisasi Pendidikan, Bumi Aksara, Jakarta, hlm vii. 
metode analisisnya menggunakan tahap reduksi data, tahap penyajian data, dan tahap klarifikasi.

\section{Konsep Budaya Sekolah Islami}

Kata budaya yang dipakai di Indonesia berasal dari kata buddayah yang berarti akal. ${ }^{3}$ Budaya hanya dicapai dengan kemampuan akal yang tinggi yang dimiliki manusia. Sementara dari bahasa Yunani, budaya (Inggris: culture) berasal dari kata colere yang berarti mengolah atau mengerjakan. Koentjaraningrat mendefinisikan kebudayaan sebagai seluruh sistem gagasan, tindakan, dan hasil karya manusia dalam rangka kehidupan masyarakat yang dijadikan manusia dengan belajar. ${ }^{4}$ Ralph Linton sebagaimana disebutkan oleh Meinarno, mendefinisikan kebudayaan; culture is a configuration of learned behavior and result of behavior whose component elements are shared and transmitted by the member of particular society. ${ }^{5}$

Dari dua pandangan tersebut, membawa pemahaman bahwa kebudayaan ada di tengah-tengah masyarakat, muncul dalam tingkah laku dan yang utama adalah dipelajari bukan terlahir begitu saja. Kottak, sebagaimana disebutkan Meinarno, mengajukan definisi yang mendekati pada pemahaman bahwa kebudayaan itu harus dijelaskan lebih luas dari sekedar definisi. Kottak melihatnya sebagai proses sehingga membuka banyak halaman. Ia menyatakan bahwa kebudayaan itu harus dipelajari. Pembelajaran tersebut melalui enkulturasi, yakni proses sosial

${ }^{3}$ Meinarno, Eko A., dkk. 2011, Manusia dalam Kebudayaan dan Masyarakat, Pandangan Antropologi dan Sosiologi, Salemba Humanika, Jakarta, hlm 90.

${ }^{4}$ Prof. Dr. Koentjaraningrat, 2009, Pengantar Ilmu Antropologi, Rineka Cipta, Jakarta, hlm 144.

${ }^{5}$ Meinarno, Eko A., dkk. 2011, Manusia dalam Kebudayaan dan Masyarakat, Pandangan Antropologi dan Sosiologi..., hlm 90. 
budaya yang dipelajari dan ditransmisikan dari generasi ke generasi. Pembelajaran dengan cara ini membuka peluang bahwa pembelajaran ini dapat melalui banyak halaman. Misalnya melalui simbol yang merupakan sebuah tanda yang tidak ada hubungannya dengan sesuatu yang diwakilinya. Gambar bulan bintang dapat dianggap sebagai simbol Islam, padahal Islam sendiri tidak terkait dengan bulan dan bintang. Jalur lain dari enkulturasi adalah melalui observasi. Hal ini sehari-hari dapat kita perhatikan di sekeliling kita, khususnya pada anak-anak yang dapat belajar cukup dengan melihat aktivitas orang dewasa di hadapannya. ${ }^{6}$

Roger M. Keesing mengemukaan beberapa definisi tentang budaya dari beberapa pendapat antara lain: Tylor (1871) yang mendefinisikan budaya adalah suatu keseluruan kompleks yang meliputi pengetahuan, kepercayaan, seni, kesusilaan, hukum, adat istiadat, serta kesanggupan dan kebiasaan lainnya yang dipelajari oleh manusia sebagai anggota masyarakat; Linton (1940) mendefinisikan budaya adalah "keseluruhan dari pengetahuan, sikap dan pola perilaku yang merupakan kebiasaan yang dimiliki dan diwariskan oleh anggota suatu masyarakat tertentu; Kroeber (1948) mendefinisikan budaya adalah keseluruhan relasi gerak, kebiasaan, tatacara, gagasan dan nilainilai yang dipelajari dan diwariskan - dan perilaku yang ditimbulkannya. ${ }^{7}$

Kebudayaan bukan milik seorang saja. Ia mendapatkannya justru karena ia adalah anggota dari suatu kelompok. Dalam suatu, di situlah kemudian seseorang mendapatkan konsepkonsep, misalnya belief (keyakinan), nilai-nilai dan cerita-cerita (ingatan bersama). Oleh karena itu, satu individu dalam satu

${ }^{6}$ Meinarno, Eko A., dkk. 2011, Manusia dalam Kebudayaan dan Masyarakat, Pandangan Antropologi dan Sosiologi..., hlm 90.

7 Roger M. Keesing, 1981, Antropologi Budaya Suatu Perspektif Kontemporer, Erlangga, Jakarta, hlm 68. 
masyarakat terbuka kemungkinan untuk memiliki pengetahuan yang relatif sama dengan individu lainnya. Karena kebudayaan dibagi (shared) dari, untuk, dan oleh anggota kelompoknya.

Kebudayaan merupakan satu kesatuan dari banyak hal, termasuk sistem masyarakat (terintegrasi). ${ }^{8}$ Koentjaraningrat menyebutkan unsur-unsur universal dari kebudayaan, yaitu meliputi: (1) bahasa, (2) sistem pengetahuan, (3) organisasi kemasyarakatan, (4) sistem teknologi dan peralatan hidup, (5) sistem mata pencaharian hidup, (6) sistem religi dan upacara keagamaan, dan (7) kesenian. ${ }^{9}$ Selanjutnya dijelaskan bahwa budaya itu paling sedikit mempunyai tiga wujud, yaitu kebudayaan sebagai: (1) suatu kompleks ide-ide, gagasan, nilainilai, norma-norma, peraturan dan sebagainya; (2) suatu kompleks aktivitas kelakukan dari manusia dalam masyarakat; dan (3) sebagai benda-benda karya manusia. ${ }^{10}$

Wujud pertama adalah wujud ide kebudayaan yang sifatnya abstrak, tak dapat diraba dan difoto. Lokasinya berada dalam alam pikiran dari warga masyarakat tempat kebudayaan yang bersangkutan hidup. Pada saat sekarang ini kebudayaan ide juga banyak tersimpan dalam disk, tape, arsip, koleksi microfilm dan sebagainya. Kebudayaan ide ini dapat disebut tata-kelakuan, karena berfungsi sebagai tata-kelakuan yang mengatur, mengendalikan, dan memberi arah kepada kelakuan dan perbuatan manusia.

Wujud kedua dari kebudayaan sering disebut sebagai sistem sosial, yang menunjuk pada perilaku yang berpola dari manusia. Sistem sosial berupa aktivitas-aktivitas manusia yang

${ }^{8}$ Meinarno, Eko A., dkk. 2011, Manusia dalam Kebudayaan dan Masyarakat, Pandangan Antropologi dan Sosiologi..., hlm 93.

${ }^{9}$ Prof. Dr. Koentjaraningrat, 2009, Pengantar Ilmu Antropologi..., hlm 165.

${ }^{10}$ Prof. Dr. Koentjaraningrat, 2009, Pengantar Ilmu Antropologi..., hlm 150. 
berinteraksi, berhubungan serta bergaul dari waktu ke waktu. Sedangkan wujud ketiga dari kebudayaan disebut kebudayaan fisik, yaitu keseluruhan hasil dari aktivitas fisik, perbuatan dan karya manusia dalam masyarakat yang sifatnya kongkrit berupa benda-benda.

Wujud dari kebudayaan, dalam konteks sekolah disebut dengan budaya sekolah. Menurut Deal dan Peterson yang dikutip oleh Muhaimin dalam bukunya Nuansa Baru Pendidikan Islam menyatakan "Budaya sekolah sebagai sekumpulan nilai yang melandasi perilaku, tradisi, kebiasaan, keseharian, dan simbolsimbol yang dipraktikkan oleh kepala sekolah, guru, petugas administrasi, siswa, masyarakat sekitar sekolah". ${ }^{11}$

Menurut Aan Komariah, dkk. dalam bukunya Visionary Leadership Menuju Sekolah Efektif mengartikan budaya sekolah sebagai karakteristik khas sekolah yang dapat diidentifikasi melalui nilai yang dianutnya, sikap, kebiasaan-kebiasaan yang ditampilkannya, dan tindakan yang ditunjukkan oleh seluruh personal sekolah yang membentuk satu kesatuan khusus dari sistem sekolah. ${ }^{12}$ Menurut Jerald Greenberg yang dikutip oleh Ansar, Budaya Sekolah adalah kerangka kerja yang disadari, terdiri dari sikap-sikap, nilai-nilai, norma-norma, perilakuperilaku dan harapan-harapan diantara warga sekolah. ${ }^{13}$

Dari beberapa pendapat tersebut di atas, maka budaya sekolah memiliki tiga unsur, yaitu sebagaimana dikatakan oleh Koentjaraningrat di atas: 1) berupa fisik seperti bangunan gedung sekolah sebagai tempat untuk ruang belajar, ruang administrasi,

11 Muhaimin, 2006, Nuansa Baru Pendidikan Islam Mengurai Benang Kusut Dunia Pendidikan, Edisi I, Jakarta, PT RajaGrafindo Persada, hlm 133.

${ }^{12}$ Aan Komariah, dan Cepi Triana, 2005, Visionary Leadership Menuju Sekolah Efektif, Cet. I, Jakarta, Bumi Aksara, hlm 102.

13 Ansar, Budaya Sekolah dalam Implementasi Manajemen Berbasis Sekolah, (http:/www.google.com.) (online) diakses 17 Nopember 2016. 
ruang guru, ruang kepala sekolah, masjid atau mushalla, kantin, halaman sekolah, tempat parkir, dan lapangan olah raga; 2) adanya sistem sosial, yang menunjuk pada perilaku yang disepakati oleh warga sekolah, seperti peraturan sekolah, program pembelajaran, program pembinaan siswa dan karyawan, tata-tertib sekolah dan lain sebagainya; 3) adanya ide atau gagasan yang melatarbelakangi tentang perilaku yang ditampilkan oleh warga sekolah. Ide inilah yang melandasi pentingnya adanya perilaku-perilaku yang disepakati bersama.

Wujud dari kebudayaan, dalam konteks sekolah disebut dengan budaya sekolah. Adapun sekolah islami adalah lembaga pendidikan yang menjadikan Islam sebagai dasar dalam menentukan visi dan misinya, serta nilai-nilai yang diterapkan dalam pelaksanaan pendidikan. Sehingga kata 'islami' dalam konteks sekolah islami menunjukkan bahwa sekolah tersebut menjadikan Islam sebagai ciri khas dalam menentukan segala hal dalam pelaksanaan pendidikannya.

Di samping itu sekolah Islami adalah sekolah yang menjadikan ajaran Islam sebagai dasar nilai dalam menata dan mengatur perilaku-perilaku subyek yang berkaitan dengan sekolah. Di lihat dari kurikulumnya terdapat mata pelajaran agama Islam dengan berbagai variasinya. Dilihat dari kegiatan sekolah setiap hari berusaha mengamalkan ajaran agama Islam, misalnya adalah hal berpakaian, siswa-siswi harus mengikuti aturan dalam Islam, demikian pula para guru dan staf di sekolah harus berbusana islami. Pergaulan antar siswa atau guru dengan siswa menerapkan akhlak pergaulan dalam Islam; saling menghormati, menebarkan salam, senyum dan sapa diantara mereka. Kesimpulannya bahwa seluruh warga sekolah harus konsen dalam mengamalkan ajaran agama Islam terutama pelaksanaan ibadah dan pengamalan akhlakul karimah.

Adapun komponen-komponen yang menjadi ciri dan lingkup Budaya Sekolah Islami menurut M. Rofiq Anwar, 
mencakup: 1) membangun Islamic Learning Society; 2) gerakan shalat berjamaah; 3) gerakan berbusana islami; 4) gerakan thaharah; 5) gerakan keteladanan; 6) gerakan keramahan Islami; dan 7) gerakan kualitas hidup. ${ }^{14}$

\section{Budaya Sekolah Islami di SMA Islam Sultan Agung 1 Semarang}

SMA Islam Sultan Agung di bawah Yayasan Badan Wakaf Sultan Agung (YBWSA). Berdiri pada tanggal 2 Januari 1966 berlokasi di Jalan Mataram 657 Semarang, ini mempunyai Visi sebagai Lembaga Pendidikan Menengah Umum Islam terkemuka dalam pendidikan, pendalaman dan penghayatan nilai-nilai Islam, dan penguasaan dasar-dasar ilmu pengetahuan dan teknologi (iptek) untuk mempersiapkan kader-kader generasi khaira ummah. Dismaping itu, misi dan tujuannya ialah menyelenggarakan pendidikan menengah umum Islam dalam rangka dakwah islamiyah yang berorientasi pada kualitas dan kesetaraan universal dengan menciptakan budaya sekolah Islami. $^{15}$

Bahasan Busi di SMA Islam Sultan Agung 1 Semarang mencakup konsep Busi, pelaksanaan Busi, dan hambatanhambatan dalam penerapan Busi di SMA Islam Sultan Agung 1 Semarang.

1. Konsep Budaya Sekolah Islami

Budaya Sekolah Islami di SMA Islam Sultan Agung 1 Semarang, munculnya dilatar belakangi oleh adanya berbagai fenomena yang muncul di kalangan masyarakat terutama para generasi muda yang banyak terlibat dalam

${ }^{14}$ Dr. dr. M. Rofiq Anwar, 1431/2010, Risalah Bismillah Membangun Generasi Khaira Ummah, Yayasan Badan Waqaf Sultan Agung, Bandungan Semarang, hlm 53-73.

15 Maryono, Tim BUSI SMA Islam Sultan Agung 1 Semarang, “Budaya Sekolah Islam”, Sabila Edisi 37, Juni 2012, hlm 1-5. 
kenakalan remaja, tawuran antar pelajar, kecanduan obatobatan terlarang dan berbagai penyimpangan pergaulan. Sungguh hal ini sangat memprihatinkan. Sehingga sekolah perlu membekali para siswa agar jangan sampai masuk ke dalam lingkaran pergaulan menyimpang tersebut. Di samping itu, sesuai dengan visi misi sekolah untuk mempersiapkan generasi khaira ummah, maka SMA Islam Sultan Agung 1 Semarang melakukan sebuah gerakan untuk mewujudkan visi dan misi tersebut. Dari sinilah kemudian muncul gerakan budaya sekolah islami, sebagaimana yang disampaikan oleh Nur Akhlis:

"SMA Islam Sultan Agung 1 Semarang sebagai bagian dari Yayasan Badan Wakaf Sultan Agung (YBWSA) memiliki tugas untuk mempersiapkan generasi yang betul-betul memiliki kualitas dalam ilmu pengetahuan dan teknologi dan agama sekaligus. Bermula dari sebuah keprihatinan tentang banyaknya generasi muda yang menjadi korban kenakalan remaja, narkoba, pergaulan bebas dan lain sebagainya. Sementara masa depan bangsa tergantung pada generasi mudanya. Sehingga untuk kepentingan memperbaiki dan mempersiapkan generasi yang memiliki moral, dan ilmu pengetahuan yang kuat serta pengamalan agama yang benar sesuai dengan alQur'an dan Hadits, maka sekolah ini perlu mengadakan gerakan membangun generasi, dan itu semua harus dimulai dari sekolah. Inilah yang menjadi latar belakang

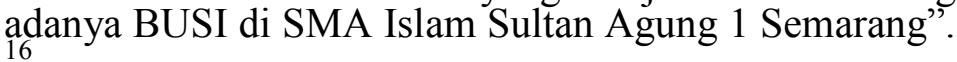

Jadi munculnya adanya ide gerakan budaya sekolah islami, yang pertama adalah adanya keinginan untuk mempersiapkan para siswa yang betul-betul menguasai ilmu pengetahuan dan agama sekaligus, yang tidak hanya dipahami dan dikuasai secara teoritis tetapi juga dipraktikkan dalam kehidupan sehari-hari, dan harus dimulai dari sekolah.

${ }^{16}$ Wawancara dengan Nur Akhlis, 5 Agustus 2016. 
Di samping itu, yang kedua, munculnya ide gerakan budaya sekolah islami itu dikarenakan adanya dukungan secara penuh dari yayasan bahwa sekolah yang ada di bawah naungan Yayasan Badan Wakaf Sultan Agung harus menerapkan budaya sekolah islami. Keharusan menerapkan budaya sekolah islami ini sebenarnya merupakan kelanjutan dari ide budaya akademik islami yang telah lebih duhulu diterapkan di Unissula. Sunhaji mengatakan; "Terinspirasi adanya Budai (Budaya Akademik Islami) di Unissula, yang kemudian dilaksanakan di Dikdasmen (Pendidikan Dasar dan Menengah) Yayasan Badan Wakaf Sultan Agung, salah satunya adalah SMA Islam Sultan Agung 1 Semarang ini. Di SMA Islam Sultan Agung 1 dinamakan dengan gerakan Busi (Budaya Sekolah Islami)".

Jadi budaya sekolah islami ini merupakan kelanjutan budaya akademi islami yang diterapkan di Universitas Islam Sultan Agung (Unissula). Sehingga kalau dilihat dari gerakan budaya yang dilakukan dalam budaya sekolah islami tidak berbeda dengan gerakan budaya akademik yang dilakukan di Unissula, seperti gerakan berjamaah, gerakan berbusana islami, gerakan pergaulan islami dan sebagainya. Demikian pula landasan yang digunakan pun memiliki kesesesuaian antara budaya sekolah islami dengan budaya akademik islami di Unissula. Unissula yang memiliki visi dan misi yang dikemas dalam sebuah motto; bismillah membangun generasi khaira ummah. Untuk membangun generasi khaira ummah, diupayakan mulai dari mempersiapkan calon generasi yang siap mengikuti agenda generasi khaira ummah. Karena itu visi dan misi SMA Islam Sultan Agung 1 Semarang adalah mempersiapkan generasi khaira ummah. Dengan demikian dapat disimpulkan bahwa ide tentang adanya Busi adalah; 1) keinginan sekolah untuk membekali siswa dengan ilmu pengetahuan dan agama yang kuat yang 
tidak hanya secara teoritis, tetapi juga secara praktis dapat diamalkan melalui kebiasaan; 2) mempersiapkan generasi khaira ummah. Untuk membangun generasi khaira ummah, ikhtiyarnya harus dimulai dari bawah dengan memberikan bekal yang kuat kepada generasi muda melalui pembentukan sikap dan akhlak.

Dasar dan tujuan Busi. Secara normatif dasar pelaksanaan Busi adalah QS. Ali Imran/2: 110, yaitu membentuk generasi khaira ummah. Sebagaimana Nur Akhlis katakan; "Dasar pelaksanaan Busi adalah membentuk generasi khaira ummah, generasi yang unggul yang mampu melaksanakan amar makruf nahi munkar dan beriman kepada Allah". Demikian pula Sunhaji; "Dasar pelaksanaan Busi adalah QS. Ali Imran/2: 110, yaitu: membentuk atau mempersiapkan generasi khaira ummah dan Sunnah Rasulullah tentang amar makruf nahi munkar dan dakwah Islamiyah". Sunhaji menambahkan hadits Nabi saw tentang perintah amar ma'ruf nahi munkar, tetapi beliau tidak menyebutkan haditsnya. Dalam QS. Ali-Imran/2: 110 disebutkan bahwa;

"Kamu adalah umat yang terbaik yang dilahirkan untuk manusia, menyuruh kepada yang ma'ruf, dan mencegah dari yang munkar, dan beriman kepada Allah. Sekiranya ahli kitab beriman, tentulah itu lebih baik bagi mereka, di antara mereka ada yang beriman, dan kebanyakan mereka adalah orang-orang yang fasik".

Berdasarkan QS. Ali Imran/3: 110 ini disebutkan bahwa kamu sekalian adalah umat yang terbaik, generasi khaira ummah yang dilahirkan untuk manusia, yang memiliki tugas menyuruh kepada yang ma'ruf dan mencegah yang munkar, dan beriman kepada Allah. Umat yang terbaik (generasi khaira ummah) yang disebutkan dalam ayat tersebut yang kemudian dijadikan motto sekolah yaitu mempersiapkan generasi khaira ummah. Hal ini memberikan pemahaman 
bahwa semangat melaksanakan budaya sekolah islami adalah karena semangat ingin membentuk atau mempersiapkan generasi khaira ummah yang disebutkan dalam ayat tersebut. Hal inilah yang kemudian mendasari warga sekolah dalam setiap aktivitasnya sedapat mungkin dapat merefleksikan pengamalan pesan-pesan Allah yaitu dalam rangka melaksanakan amar ma'ruf (memerintahkan yang baik) dan nahi munkar (mencegah perbuatan yang tidak baik) serta beriman kepada Allah.

Berdasarkan ayat 110 Surah Ali Imran tersebut, secara normatif yang hendak dilakukan oleh sekolah adalah semangat mengamalkan al-Qur'an bagi seluruh warga sekolah terutama mengamalkan perintah untuk berdakwah yang salah satunya adalah amar ma'ruf nahi munkar (memerintah yang baik dan mencegah yang munkar), dan semangat untuk meningkatkan iman. Iman yang tidak sekedar percaya tetapi keimanan yang dapat dibuktikan dalam bentuk perbuatan. Dan cerminan iman bagi warga sekolah salah satunya yang harus dilaksanakan secara bersama-sama adalah membudayakan sekolah islami yang dikemas dengan gerakan budaya sekolah islami.

Koentjaraningrat menjelaskan bahwa budaya itu paling sedikit mempunyai tiga wujud, yaitu kebudayaan sebagai: (1) suatu kompleks ide-ide, gagasan, nilai-nilai, normanorma, peraturan dan sebagainya; (2) suatu kompleks aktivitas kelakukan dari manusia dalam masyarakat; dan (3) sebagai benda-benda karya manusia. Berdasarkan pernyataan Koenjtaraningrat tersebut maka konsep tentang budaya sekolah islami ini memiliki dasar yang sangat kuat dan relevan dengan pesan-pesan al-Qur'an yang memerintahkan untuk beramar ma'ruf nahi munkar. Sehingga bagi seluruh warga sekolah yang betul-betul telah memahami dasar budaya sekolah islami akan lebih 
maksimal dan mantap dalam melaksanakan budaya sekolah islami ini.

Adapun secara formal, Busi dilaksanakan berdasarkan keputusan yayasan yang mengharuskan kepada seluruh lembaga yang ada di bawahnya untuk menerapkan budaya Islam bagi pengurus dan seluruh karyawannya. Keputusan yayasan ini, kemudian disetujui dan direspon oleh seluruh lembaga yang ada di bawah yayasan, dan kemudian dirumuskan tentang budaya islami yang diterapkan di sekolah mulai sekolah dasar, sekolah menengah pertama, sekolah menengah atas menggunakan nama Budaya Sekolah Islami. Adapun budaya islami yang diterapkan di rumah sakit dinamakan Budaya Rumah Sakit Islami (Bursi), dan budaya islami yang diterapkan di universitas (Unissula) dinamakan Budaya Akademik Islami (Budai).

Pelaksanaan Busi secara formal mendapatkan dukungan penuh dari badan penyelenggara pendidikan, dalam hal ini Yayasan Badan Wakaf Sultan Agung. Di samping itu, seluruh warga sekolah sangat mendukung adanya Busi. Karena ada Busi ini, sebetulnya juga dalam rangka pengamalan nilai-nilai Islam. Adapun tujuan diterapkan Busi di SMA Islam Sultan Agung 1 Semarang Sebagaimana yang disampaikan Nur Akhlis mengatakan;

"Tujuan Busi adalah agar para siswa memiliki akhlaqul karimah, yang berwujud dalam hubungannya dengan orang tua, guru, dan masyarakat, serta memiliki perilaku ibadah yang benar". Sedangkan Sunhaji mengatakan; "Tujuan dari Busi adalah merupakan kesinambungan dengan Budai yang ada di Unissula, membangun generasi khaira ummah, agar anak terbiasa menjalankan amalan yang biasa dilaksanakan di sekolah (misalnya malu jika tidak shalat berjamaah)". Sunhaji selanjutnya mengatakan; "Dengan adanya Busi ini, diharapkan siswa memiliki kebiasaan amalan yang baik, yang biasa dilakukan di sekolah. Siswa terbiasa melaksanakan shalat berjama'ah, terbiasa tadarus al-Qur'an, peduli terhadap 
kebersihan lingkungan, dan terbiasa menampilkan diri dengan perilaku yang baik". ${ }^{17}$

Dari penuturan Nur Akhlis dan Sunhaji dapat disimpulkan bahwa tujuan budaya sekolah islami di SMA Islam Sultan Agung 1 Semarang adalah; 1) agar para siswa memiliki akhlak yang mulia (akhlaqul karimah); 2) siswa terbiasa melaksanakan kewajiban agama dengan baik; 3) mempersiapkan generasi khaira ummah; 4) siswa terbiasa menampilkan diri dengan baik di lingkungannya.

2. Pelaksanaan Budaya Sekolah Islami

Gerakan Busi di SMA Islam Sultan Agung 1 Semarang diterapkan mulai pada tahun ajaran 2009/2010. Dan ini dilakukan sesuai instruksi dari yayasan (YBWSA) untuk menerapkan Budaya Sekolah Islami. Penerapan budaya sekolah islami ini, sebagaimana yang disampaikan Nur Akhlis dan Sunhaji, merupakan kelanjutan Budaya Akademik Islami yang diterapkan di UNISSULA (Universitas Sultan Agung) . Hal ini karena yayasan sebagai lembaga penyelenggara pendidikan berkehendak agar nilainilai budaya Islam (Budai) dapat diterapkan di semua lembaga yang ada di bawah naungannya. ${ }^{18}$

Budai di Unissula mulai diterapkan secara formal sebagai gerakan Budaya Akademik Islami sesuai SK Rektor yaitu pada tahun 2007. Muchamad Rosul mengatakan: "Bentuk nyata pelaksanaan Budaya Akademik Islami di Unissula dibagi dalam beberapa bentuk meliputi islamisasi dalam proses belajar mengajar di kelas, laboratorium, studio maupun lapangan, tata cara berbusana, dalam pergaulan, shalat berjamaah, dan larangan merokok (sesuai SK Rektor

${ }^{17}$ Wawancara dengan Sunhaji, 5 Agustus 2016.

${ }^{18}$ Wawancara dengan Nur Akhlis dan Sunhaji, 5 Oktober 2016. 
Unissula tahun 2007)". ${ }^{19}$ Tetapi awal sebelum ada surat keputusan Rektor Unissula, kegiatan Budai sudah dilaksanakan sosialisasi melalui berbagai pelatihanpelatihan. Abdurrohim, S. Psi., M. Si. mengatakan; "Sejak tahun 2005 sampai sekarang, Budai selangkah-demi selangkah mulai diterapkan di lingkungan kampus Unissula...." ${ }^{20}$ Ini artinya bahwa setelah Budaya Akademik Islami di Unissula telah mantap dilaksanakan, maka diikuti dengan pelaksanaan Budaya Sekolah Islami di sekolah di bawah naungan Yayasan Badan Wakaf Sultan Agung.

Jadi, Busi sebagai gerakan Budaya Sekolah Islami muncul setelah gerakan Budaya Akademik Islami di Unissula. Dan ini berarti bahwa gerakan Busi betul-betul sebuah gerakan yang terbangun secara terstruktur dari pihak yayasan sebagai pihak penyelenggara pendidikan dasar dan menengah. Bahkan dari yayasan inilah semua lembaga yang berada di bawahnya diharuskan menerapkan sebuah gerakan budaya Islam.

Busi di SMA Islam Sultan Agung 1 Semarang telah berjalan sejak pertama diterapkan pada tahun 2009. Sebagai gerakan budaya, Busi terus menerus diupayakan dan ditingkatkan agar betul-betul dapat dilaksanakan dengan baik oleh seluruh warga sekolah, terutama siswa sebagai calon generasi khaira ummah. Dari gerakan budaya sekolah ini, secara fisik, sekolah telah membenahi dan melengkapi sarana dan prasarana yang diperlukan untuk pelaksanaan Budaya Sekolah Islami, antara lain: menambah tempat untuk berwudhu dan toilet, memperluas masjid tempat untuk shalat

19 Drs. H. Ali Bowo Tjahjono, M. Pd., (ed), 2007, Bunga Rampai Budai, Jilbab Antara Kewajiban dan Tren, Unissula Press, Semarang, hlm 97-98.

${ }^{20}$ Drs. H. Ali Bowo Tjahjono, M. Pd., (ed), 2007, Bunga Rampai Budai..., hlm 117. 
berjamaah, dan peralatan-peralatan yang diperlukan untuk kebersihan lingkungan. Sehingga kalau dilihat dari segi fisik, lingkungan sekolah sangat kondusif untuk pelaksanaan Budaya Sekolah Islami.

Adanya Budaya Sekolah Islami di sekolah, memberikan dampak yang sangat positif bagi warga sekolah terutama siswa. Hal ini diakui oleh salah satu siswa yaitu Indra Widie S siswa kelas XII yang mengakui bahwa Busi di SMA Islam Sultan Agung 1 Semarang ternyata sangat bermanfaat dan baik baginya. Indra Widie S mengatakan; "Ternyata Busi baik sekali, karena kita mengetahui lebih banyak tentang agama Islam. Dan ini betul-betul memberikan banyak manfaat bagi kami. Terutama dalam pergaulan sehari-hari di dalam maupun di luar kelas". ${ }^{21}$

Materi Busi yang diterapkan di SMA Islam Sultan Agung 1 Semarang adalah sebagaimana penuturan Nur Akhlis dan Sunhaji; bahwa materi Busi terdiri dari: a) Budaya Iqra' meliputi iqra' literasi dan tadarus al-Qur' an; b) budaya shalat berjamaah; c) budaya thaharah; d) budaya pergaulan islami termasuk berbusana; e) gerakan keteladanan. ${ }^{22}$

Adapun Langkah-langkah penerapan Busi melalui tiga tahapan:

1. Busi dikenalkan dan diterapkan di SMA Islam Sultan Agung 1 Semarang yaitu pada tahun pelajaran 2009/2010. Pada tahap ini dilakukan sosialisasi Busi kepada warga sekolah oleh tim motivator yang terdiri dari pejabat struktural; kepala sekolah dan wakil kepala sekolah ditambah dengan guru agama. Sosialisasi Busi kepada siswa dilakukan sajak awal mereka masuk sekolah, saat siswa baru mengikuti kegiatan masa orientasi siswa baru (MOS).

\footnotetext{
21 Wawancara dengan Indra Widie S., 8 Agustus 2016.

22 Wawancara dengan Nur Akhlis dan Sunhaji, 5 Agustus 2016.
} 
Sedangkan sosialisasi kepada guru dan karyawan disampaikan melalui rapat guru dan rapat sekolah.

Tim motivator ini bertugas menggerakkan seluruh warga sekolah untuk melaksanakan Busi, dengan cara menyampaikan secara lisan ke seluruh warga sekolah tentang pentingnya Busi, misalnya; penjelasan melalui forum rapat guru atau upacara, dan sosialisasi ke seluruh kelas. Tahapan ini dilakukan sampai tahun 2012. Pada tahap ini, berdasarkan penuturan Sunhaji dan Nur Akhlis bahwa pelaksanaan Busi dimulai dari sosialisasi keseluruh warga sekolah mulai tahun 2009 sampai tahun 2012 oleh tim motivator. Tugas motivator ini adalah mensosialisakan budaya sekolah islami sampai seluruh warga sekolah memahami pentingnya dan perlunya gerakan Busi. Kemudian setelah tahun 2012, dianggap perlu meningkatkan pelaksanaan budaya sekolah islami. Maka dibentuklah tim motivator dari siswa.

2. Tahap kedua adalah tahap di mana dalam pelaksanaan Busi melibatkan siswa sebagai tim motivator. Tahap ini dimulai pada tahun 2012, di mana masing-masing kelas ditunjuk satu orang siswa untuk menjadi tim motivator. Tugas motivator siswa adalah menggerakkan teman-teman sekelasnya untuk melaksanakan kegiatan-kegiatan yang tercakup dalam kegiatan busi, seperti pelaksanaan shalat berjamaah. Caranya mengingatkan kepada seluruh kelas untuk segera melaksanakan shalat berjamaah bilamana waktu telah tiba. Tim motivator ini masih berjalan sampai sekarang.

Nur Akhlis mengatakan; "Kemudian mulai tahun 2012 dibentuk motivator dari siswa, yaitu masing-masing kelas diambil satu orang siswa untuk menjadi motivator."23 Dengan adanya tim motivator dari siswa, bukan berarti tugas

${ }^{23}$ Wawancara dengan Nur Akhlis, 5 Agustus 2016. 
motivator pada tahap pertama selesai, tetapi secara otomatis motivator pada tahap awal tugasnya melekat sebagai warga sekolah yang seluruhnya harus menjadi motivator pelaksanaan Busi.

Pada tahap kedua pelaksanaan budaya sekolah islami ini, menunjukkan adanya peningkatan gerakan budaya sekolah islami, terutama siswa. Karena mereka mendapatkan kontrol dan motivasi dari sesama siswa. Ini juga menunjukkan bahwa pelaksanaan budaya sekolah islami oleh siswa lebih mudah jika yang menggerakkan sesama siswa. Indra Widie $\mathrm{S}$ salah seorang siswa yang menjadi motivator dan ketua Rohis (Rohani Islam) mengatakan; "Sebagai ketua Rahis, dulu saya selalu mengajak teman-teman terdekat, dan memotivasi teman-teman agar melaksanakan Busi'" ${ }^{24}$

3. Tahap pemantapan adalah tahap di mana pelaksanaan Busi diharapkan telah menjadi bagian dari budaya sekolah. Sehingga materi Busi yang telah diterapkan sejak awal betulbetul sudah dilaksanakan oleh seluruh warga sekolah, dan pelaksanaan Busi di lapangan tidak lagi tergantung pada tim motivator tetapi seluruh warga sekolah telah menyadari bahwa mereka sebagai motivator, dan bertanggung jawab untuk kelangsungan Busi.

Tahap ini dimulai setelah tahun 2012, di mana seluruh warga sekolah bertanggung jawab secara jamaah untuk melaksanakan Busi. Nur Akhlis mengatakan; "...Dan bersamaan dengan itu setelah tahun 2012 semuanya (guru dan siswa) menjadi motivator sampai sekarang". ${ }^{25}$ Langkah berikutnya yang dilakukan oleh tim motivator adalah membuat slogan-slogan bernuansa ajakan berbuat baik, dan mengajak warga sekolah melalui pengeras suara untuk

\footnotetext{
24 Wawancara dengan Indra Widie S., 8 Agustus 2016.

${ }^{25}$ Wawancara dengan Nur Akhlis, 5 Agustus 2016
} 
kegiatan-kegiatan tertentu, seperti shalat berjamaah. Ini dilakukan secara terus-menerus. Dan alhamdulillah - kata Nur Akhlis - bahwa "sekarang sudah menjadi budaya sekolah, dan telah muncul kesadaran secara jamaah dari siswa". ${ }^{26}$ Hal ini juga seperti yang dinyatakan oleh Sunhaji; "Sekarang, tim motivator Busi melekat ke semua warga sekolah; kepala sekolah, guru, siswa , dan staf sekolah." 27 Demikian pula Siti Mubarokatut Darojah selaku Kepala Sekolah menyatakan bahwa sekarang (maksudnya tahun 2016) budaya sekolah islami sudah melekat pada seluruh kegiatan yang ada. ${ }^{28}$

Berhubungan dengan penanggung jawab pelaksanaan Busi, Nur Akhlis mengatakan; "bahwa pada mulanya Busi meruapakan tanggung jawab wakil kepala sekolah bagian kesiswaan. Dan dalam pelaksanaan di lapangan dibentuk motivator yang terdiri dari para guru agama dan siswa. Tetapi sekarang sudah menjadi tanggung jawab bersama di bawah kepemimpinan kepala sekolah". ${ }^{29}$ Demikian pula Sunhaji mengatakan; "Penanggung jawab secara khusus, pada mulanya adalah wakil kepala sekolah bidang kesiswaan. Tetapi sekarang, pelaksanaan Busi di sini sudah merupakan tanggung jawab bersama, sehingga masingmasing warga sekolah bertanggung jawab terhadap pelaksanaan Busi". ${ }^{30}$

Jadi pada saat ini Busi telah menjadi budaya bagi seluruh warga sekolah. Oleh karena itu, seluruh warga sekolah harus mendukung gerakan budaya sekolah islami di SMA Islam Sultan Agung 1 Semarang.

\footnotetext{
${ }^{26}$ Wawancara dengan Nur Akhlis, 5 Agustus 2016

27 Wawancara dengan Sunhaji, 5 Agustus 2016.

${ }^{28}$ Wawancara dengan Siti Mubarokatud Darojah, 5 Agustus 2016.

${ }^{29}$ Wawancara dengan Nur Akhlis, 5 Agustus 2016.

30 Sunhaji, Wawanacara tanggal 5 Agustus 2016.
} 
Suasana sekolah kaitannya dengan penerapan Busi di SMA Islam Sultan Agung 1, terlihat rapi dalam pelaksanaan shalat berjamaah, dan perilaku-perilaku para siswa baik dengan guru maupun dengan siswa. Siswa telah terbiasa melaksanakan shalat berjamaah. Walaupun pada mulanya sesuai dengan aturan, bahwa mereka diwajibkan mengikuti shalat berjamaah. Tetapi lama-kelamaan telah menjadi kebiasaan, sehingga begitu jadwalnya shalat berjamaah, mereka segera menuju masjid. Dan yang datang lebih dahulu segera menempati shaf yang depan. Dan terlihat mereka sangat antusias untuk mengikuti shalat berjamaah. Demikian pula interaksi antara guru dengan siswa, mereka para siswa ketika bertemu dengan guru (bapak/ibu guru) di manapun mengajak berjabat tangan dan mengucapkan salam. Demikian pula pergaulan diantara para siswa terlihat sangat ramah, saling menyapa dan menebarkan salam.

Dilihat dari lingkungan fisik, sekolah terlihat sangat bersih baik di kelas maupun di luar kelas, bebas dari sampah. Para siswa pun berdisiplin mentaati peraturan sekolah, seperti berbusana, parkir kendaraan, dan mentaati jadwal-jadwal kegiatan sesuai dengan ketentuan. Tempat wudhu terlihat bersih dan mencukupi untuk jumlah siswa yang banyak. Masjid pun sangat bersih dan kondusif untuk pelaksanaan shalat berjamaah. Perlengkapan loud speaker yang terpasang secara online tersambung ke masingmasing kelas membantu mempercepat sosialisasi informasi termasuk kumandang adzan ketika waktu shalat tiba.

Secara formal tidak ada aturan secara khusus tentang Busi, tetapi aturannya melekat dengan aturan di sekolah. Dan untuk standar pelaksanaan busi aturan normatifnya sesuai dengan ajaran Islam. Hal ini sesuai dengan pernyataan Nur Akhlis dan Sunjaji. Nur Akhlis mengatakan; "Ada aturan atau pedoman khusus tetapi pedoman itu berdasar pada ajaran Islam, seperti sopan santun; berbusana, berbicara yang semuanya berdasarkan 
ajaran Islam". ${ }^{31}$ Sedangkan Sunhaji mengatakan; "Khusus tentang Busi, aturannya melekat dengan aturan sekolah". 32

Demikian pula tentang sanksi bagi yang melanggar pun aturannya mengikuti sekolah. Artinya tidak ada secara khusus aturan Busi. Sunhaji mengatakan; “...Demikian pula sanksinya pun melekat pada aturan sekolah". Adapun sanksinya - menurut Nur Akhlis, ialah "melalui teguran secara lisan, peringatan tertulis, dan secara administrasi yang dalam pelaksanaannya disesuaikan dengan bagian Bimbingan dan Konseling". ${ }^{33}$ Dalam Buku Informasi SMA Islam Sultan Agung 1 Semarang dinyatakan; "siswa yang melanggar tata tertib sekolah dikenakan sanksi secara bertingkat, yaitu; 1) sanksi teguran dan peringatan; 2) sanksi skorsing di ruang BK/dirumahkan; 3) sanksi dikembalikan ke orang tua/dikeluarkan". ${ }^{34}$

Menurut Nur Akhlis dan Sunhaji, seluruh Warga sekolah semuanya mendukung pelaksanaan Busi. Mereka merasakan manfaat dari gerakan Busi ini. Bahkan salah seorang siswa yaitu Indra Widie S, saat diwawancari tentang pelaksanaan Busi di sekolah ini. Dia menjawab; "Busi di sekolah sangat memberikan manfaat yang sangat besar. Sehingga materi Busi yang semula saya tidak terbiasa menjalankannya, setelah menjadi siswa sekolah ini, telah mendapatkan pengalaman shalat berjama'ah, membaca al-Qur'an, dan kegiatan budaya islami yang lain. Dan pengalaman ini saya terapkan juga di rumah ketika saya sudah pulang dari sekolah". ${ }^{35}$

Dari paparan di atas, tentang suasana sekolah dalam penerapan Busi, menunjukkan bahwa perlu penciptaan suasana sekolah melalui upaya membudayakan nilai-nilai islami, dan

${ }^{31}$ Nur Akhlis, Wawancara pada tanggal 5 Agustus 2016

${ }^{32}$ Sunhaji, Wawancara pada tanggal 5 Agustus 2016.

${ }^{33}$ Nur Akhlis, Wawancara pada tanggal 5 Agustus 2016.

${ }^{34}$ Buku Informasi SMA Islam Sultan Agung 1

${ }^{35}$ Indra Widie S., Wawancara pada tanggal 8 Agustus 2016. 
dukungan seluruh warga sekolah untuk menciptakan susana yang kondusif penanaman nilai-nilai islami. Ini artinya suasana sekolah pun penting dan sangat berpengaruh dalam proses pendidikan. Sehingga perubahan perilaku ke arah yang lebih baik oleh seluruh warga sekolah akan mudah tercipta manakala lingkungan sekolah juga mendungung untuk proses terjadinya perubahan.

Untuk meningkatkan gerakan budaya sekolah islami, sekolah telah melaksanakan evaluasi kegiatan busi. Evaluasi yang pertama kali adalah evaluasi tentang kinerja dari motivator dan pelaksanaan busi. Tim motivator dievaluasi, apakah telah melaksanakan tugas dengan baik atau masih harus lebih keras lagi bekerja. Sementara evalusi pelaksanaan Busi, apakah masih terdapat kekurangan dalam pelaksanaan Busi dan memerlukan perhatian.

Sunhaji mengatakan; "Evaluasinya terutama tentang sarana prasarana untuk pelaksanaan shalat jamaah. Misalnya tentang kecukupan tempat wudhu. Dari evaluasi tersebut ditemukan bahwa dalam pelaksanaan shalat berjamaah masih terdapat banyaknya siswa yang terlambat mengikuti jamaah. Evaluasi ini dilaksanakan agar pelaksanaan shalat berjamaah betul-betul terlaksana". ${ }^{36}$ Berdasarkan evaluasi kegiatan Busi ini, maka segera diadakan perbaikan di lapangan. Misalnya tentang banyaknya siswa yang terlambat shalat berjamaah dikarenakan kekurangan tempat wudhu, maka sekolah segera menambah fasilitas tempat wudhu. Dan menggerakkan siswa segera menuju masjid untuk melaksanakan shalat berjamaah setelah pelajaran selesai.

Pola pelaksanaan dengan menggunakan pola top down ini telah membawa dampak yang baik dalam penanaman budaya Islami di sekolah. Ketertiban dan kebersihan dalam pelaksanaan

${ }^{36}$ Sunhaji, Wawancara pada tanggal 5 Agustus 2016. 
nilai-nilai ibadah, shalat berjamaah di awal waktu, membaca alQur'an telah menjadi budaya bersama dan melekat dengan budaya sekolah lainnya dan telah menjadi bagian dari aktifitas segenap sivitas akademika SMA Islam Sultan Agung 1 Semarang, Sesuai dengan visi, misi dan tujuan sekolah; mewujudkan budaya sekolah islami dapat tercapai dengan baik. Dan visi mempersiapkan generasi khaira ummat dapat terwujud dengan mantap. Dan tercapailah tujuan pendidikan yang sebenarnya, yang tidak hanya mengejar ilmu pengetahuan saja tetapi juga mempersiapkan siswa-siswa yang memiliki akhlak yang mulia sebagaimana yang dipesankan dalam tujuan pendidikan Nasional; “...untuk berkembangnya potensi peserta didik agar menjadi manusia yang beriman dan bertakwa kepada Tuhan Yang Maha Esa, berakhlak mulia, sehat, berilmu, cakap, kreatif, mandiri, dan menjadi warga negara yang demokratis serta bertanggung jawab". ${ }^{37}$

\section{Penutup}

Berdasarkan pembahasan tentang Busi di SMA Islam Sultan Agung 1 Semarang dapat disimpulkan:

1. Bahwa konsep Busi di SMA Islam Sultan Agung 1 Semarang ialah merupakan suatu gerakan mempersiapkan generasi khaira ummah, generasi yang menguasai ilmu pengetahuan dan teknologi sekaligus tafaqquh fiddin, memahami dan mengamalkan nilai-nilai ajaran Islam 'amar ma'ruf nahi munkar' dalam kehidupan sehari-hari. Dan inti gerakan busi ini adalah menghidupkan dan mengamalkan nilai-nilai ajaran Islam bagi warga sekolah, sehingga pembentukan perilaku bagi siswa akan mudah dikondisikan.

37 UU RI Nomor 20 Tahun 2003 tentang Undang-Undang Sistem Pendidikan Nasional, pasal 3. 
2. materinya adalah budaya iqra', budaya shalat berjamaah, budaya thaharah, budaya pergaulan islami, dan budaya keteladanan.

3. Pola pelaksanaan Busi secara top down mendapatsikan dukungan dari yayasan sebagai penyelenggara pendidikan.

4. Pencanangan Budaya Islam telah berhasil menerapkan nilainilai Islam tersebut menyatu dalam aktifitas budaya sekolah yang lain sesuai dengan visi, misi dan tujuan lembaga

\section{Daftar Pustaka}

Ansar, Budaya Sekolah dalam Implementasi Manajemen Berbasis Sekolah, (http:/www.google.com.) (online) diakses 17 Nopember 2016.

Anwar, H. M. Rofiq, dr., Dr., Sp. PA. (Ketua Tim), 1431/2010, Risalah Bismillah Membangun Generasi Khaira Ummah, Yayasan Badan Waqaf Sultan Agung, Bandungan Semarang.

Aqib, Zainal, 2012, Pendidikan Karakter di Sekolah, Membangun Karakter dan Kepribadian Anak, Yrama Widya, Bandung.

Az-Zuhaili, Wahbah, Prof., Dr., 2014, Ensiklopedi Akhlak Muslim, Berakhlak dalam Bermasyarakat, terj. Abdul Aziz, S.S., Noura Books, Jakarta Selatan.

Az-Zuhaili, Wahbah, Prof., Dr., 2014, Ensiklopedi Akhlak Muslim, Berakhlak terhadap Sesama \& Alam Semesta, terj. Abdul Aziz, S.S., Noura Books, Jakarta Selatan.

Bogdan, Robert C. and Biklen, Sari Knopp. 1992. Qualitative Research for Education, Allyn and Bacon, Boston. 
Danim, Sudarwan. 2002. Menjadi Peneliti Kualitatif, Pustaka Setia, Bandung.

Daulay, Haidar Putra, 2004, Pendidikan Islam dalam Sistem Pendidikan Nasional di Indonesia, Jakarta, Prenada Media.

Djatnika, Rachmat, Prof. Dr. H., 1996, Sistem Ethika Islami, Pustaka Panjimas, Jakarta.

Ekosusilo, Madyo, 2003, Sistem Nilai dalam Budaya Organisasi Sekolah pada Sekolah Unggul (Disertasi), Universitar Negeri, Malang.

Faridl, Miftah, Drs., 1997, Masyarakat Ideal, Pustaka, Bandung.

Ilyas, Yunahar, Dr., Lc., M.A.,2007, Kuliah Akhlak, LPPI UMY, Yogyakarta.

Keesing, Roger M, 1981, Antropologi Budaya Suatu Perspektif Kontemporer, Erlangga, Jakarta.

Koentjaraningrat, Prof. Dr., 2009, Pengantar Ilmu Antropologi, Rineka Cipta, Jakarta.

Komariyah, Aan, Cepi Triana, 2005, Visionary Leadership Menuju Sekolah Efektif, Cet. I, Jakarta, Bumi Aksara.

Maryono, Tim BUSI SMA Islam Sultan Agung 1 Semarang, "Budaya Sekolah Islam”, Sabila Edisi 37, Juni 2012.

Meinarno, Eko A., dkk. 2011, Manusia dalam Kebudayaan dan Masyarakat, Pandangan Antropologi dan Sosiologi, Salemba Humanika, Jakarta.

Moleong, Lexy J. 2000 Metodologi Penelitian Kualitatif, Remaja Rosda Karya, Bandung. 
Muhaimin, 2005, Pengembangan Kurikulum Pendidikan Agama Islam di Sekolah, Madrasah, dan Perguruan Tinggi, Edisi I, Jakarta, PT. RajaGrafindo Persada.

Muhaimin, 2006, Nuansa Baru Pendidikan Islam Mengurai Benang Kusut Dunia Pendidikan, Edisi I, Jakarta, PT RajaGrafindo Persada.

Muhaimin, et. All., 2001, Paradigma Pendidikan Islam (Upaya Mengefektifkan PAI di Sekolah), Bandung, Remaja Rosdakarya.

Mustopa, 2014, Model Bimbingan Konseling Islami dalam Menumbuhkan Disiplin Belajar Siswa SMA Islam Sultan Agung 1 Semarang, Penelitian Individu FITK IAIN Walisongo, Semarang.

Muthohar, Sofa. "Antisipasi Degradasi Moral di Era Global." Nadwa 7, no. 2 (2016): 321-334.

Nazir, Moh. 1988. Metode Penelitian, Ghalia Indonesia, Jakarta.

Republika, 15 Pebruari 2016.

Saebani, Beni Ahmad, Drs., M.Si. dan Hamid, Abdul, Drs. KH., M. Ag. 2010, Ilmu Akhlak, Pustaka Setia, Bandung.

Sidi Gazalba, Drs., 1989, Mesjid Pusat Ibadat dan Kebudayaan Islam, Pustaka Al-Husna, Jakarta.

Syahidin, Dr., M. Pd., 2003, Pemberdayaan Umat Berbasis Masjid, Alfabeta, Bandung.

Syalabi, Ahmad., Prof. Dr., 1973, Sejarah Pendidikan Islam, Bulan Bintang, Jakarta.

Syalabi, Ahmad., Prof. Dr., 1997, Sejarah dan Kebudayaan Islam, Al-Husna Zikra, Jakarta. 
Tjahjono, Ali Bowo, H., Drs., M. Pd. (ed), 2007, Budai, Budaya Akademik Islami, Unissula Press, Semarang.

Tjahjono, Ali Bowo, H., Drs., M. Pd., (ed), 2007, Bunga Rampai Budai, Jilbab Antara Kewajiban dan Tren, Unissula Press, Semarang.

Undang-Undang Nomor 2 Tahun 2003 tentang Sistem Pendidikan Nasional, Duta Nusindo, Semarang.

Yani, Ahmad, Drs. H. dan Achmad Satori Ismail, Dr., 2001, Menuju Masjid Ideal, LP2SI Haramain, Jakarta Selatan.

Zarkasyi, Abdullah Syukri, K.H., MA., 2005, Gontor, Pembaharuan Pendidikan Pesantren, Raja Grapindo Persada, Jakarta.

Zuchdi, Darmiyati, 2011, Humanisasi Pendidikan, Bumi Aksara, Jakarta.

Zuchdi, Darmiyati, 2011, Model Pendidikan Karakter Terintegrasi dengan Pembelajaran dan Pengembangan Kultur Sekolah, UNY Press, Yogyakarta. 